Iwona Kowal

Uniwersytet Jagielloński

iwona.kowal@uj.edu.pl

\title{
RÓŻNORODNOŚĆ SPOŁECZNO-KULTUROWA SZWECJI W PODRĘCZNIKACH DO NAUKI JĘZYKA SZWEDZKIEGO
}

\author{
Sociocultural diversity in Sweden as presented \\ in Swedish language textbooks
}

The paper discusses specific features of the Swedish sociocultural reality and the way the sociocultural diversity of the country is presented in language textbooks for Swedish language learners. The analysis is longitudinal in nature i.e. it concerns two editions of textbooks published in Sweden between 1996 and 2014. The presentation of Swedish sociocultural diversity is both explicit and implicit in nature, with changes in ethnic diversity, household diversity, and family diversity being the most dynamic ones. However, a number of differences between both textbooks are noticeable: in the older version information is presented mainly in an explicit form while its newer counterpart demonstrates the diversity of Swedish society both explicitly and implicitly.

Keywords: sociocultural diversity, textbooks analysis, sociocultural situation in Sweden

Słowa kluczowe: różnorodność społeczno-kulturowa, analiza podręcznika, sytuacja społeczno-kulturowa Szwecji

\section{Wprowadzenie}

Nauka języka obcego nie ogranicza się jedynie do poznania nowych wyrazów czy struktur językowych. Równie ważne jest uzyskanie wiedzy na temat aspektów społeczno-kulturowych kraju, w którym dany język jest używany w codziennej komunikacji. Dużo łatwiejsze jest to w sytuacji, gdy nauka języka odbywa się 
w środowisku naturalnym, natomiast trudniejsze w klasie językowej, szczególnie gdy edukacja ma miejsce poza krajem, którego język jest poznawany. Wówczas niezmiernie ważnym źródłem wiedzy o języku i kulturze danego kraju staje się podręcznik. Jego rola jest szczególnie istotna przede wszystkim na początku nauki, kiedy wiele osób uczących się traktuje podręcznik jako najważniejszy, a niekiedy jedyny punkt odniesienia przy poznawaniu kraju i użytkowników języka, którego zaczyna się uczyć. Służy on zatem nie tylko do przekazywania informacji, lecz pośrednio jest także narzędziem do kształtowania postaw ucznia wobec nowej kultury, co wpływa na motywację do nauki języka oraz na rozwój kompetencji interkulturowej.

\section{Aspekty kulturowe w glottodydaktyce}

Nierozerwalność procesu nauki języka obcego z nabywaniem kompetencji interkulturowej stała się obecnie niemal aksjomatem w glottodydaktyce. Język i kultura jako nierozerwalne elementy struktury poznawczej człowieka są ze sobą ściśle powiązane. Nie można nauczyć się języka, nie poznając kultury danego kraju, ani zrozumieć kultury, nie znając języka. Sama definicja kultury jest niezmiernie obszerna i zawiera wiele definiensów. Słownik języka polskiego PWN wymienia ich siedem, wśród których na dwóch pierwszych miejscach znajdują się „materialna i umysłowa działalność społeczeństw oraz jej wytwory” oraz „społeczeństwo rozpatrywane ze względu na jego dorobek materialny i umysłowy”. Do kultury zalicza się tu także „odpowiednio wysoki poziom rozwoju społeczeństwa w jakimś zakresie” czy „umiejętność obcowania z ludźmi”. Pozostałe definiensy odnoszą się do biologii i agronomii (SJP). Wielki słownik języka polskiego PAN jako pierwsze określenie podaje „duchowy i materialny dorobek społeczności żyjącej w jakimś czasie na określonym terenie”, co w znacznym zakresie pokrywa się z pierwszym definiensem Słownika języka polskiego, przy czym według tego opisu kultura opiera się na działalności duchowej, a nie umysłowej, i stanowi wynik działalności, a nie sam akt działania. W WSJP nie pojawia się społeczeństwo jako jeden z elementów kultury, natomiast wymieniany jest „stopień opanowania pewnej umiejętności” czy „umiejętność taktownego zachowania się w każdej sytuacji”. Także i w tym słowniku spotkamy odniesienie do biologii i agronomii (WSJP). W Encyklopedii powszechnej PWN znajduje się nie tylko stwierdzenie, że kultura jest zaliczana do najbardziej popularnych terminów w humanistyce, lecz przedstawiono tam także, jak na przestrzeni dziejów zmieniało się podejście do tego zjawiska. W opisie terminu zwrócono uwagę na różnorodność ujęć oraz na dychotomię definicji i rozumienia kultury. W rozumieniu szerszym „kultura obejmuje to wszystko, co w zachowaniu się i wyposażeniu członków społeczeństw ludzkich 
stanowi rezultat zbiorowej działalności, [...] całokształt duchowego i materialnego dorobku społeczeństwa, przekazywanych z pokolenia na pokolenie wierzeń i praktyk jego członków, przyjętych przez nich wzorów postępowania”. Natomiast w ujęciu węższym kulturę stanowią teatr, literatura czy muzyka, lecz nie nauka i technika. Jednocześnie w opisie można znaleźć podsumowujące stwierdzenie, że w XX wieku zmieniono podejście i najczęściej zaczęto odnosić się do kultury jako do „zespołu wzorów rozwiązywania problemów charakterystycznego dla danego społeczeństwa, wzorów postępowania itp." (Encyklopedia powszechna PWN). I to właśnie te elementy: zachowanie się społeczeństwa, przekazywanie praktyk jego członków czy charakterystyczne wzorce rozwiązywania przez nich problemów stanowią najczęściej trzon wiedzy, którą uczniowie powinni otrzymać wraz z nauką języka obcego. Nie bez znaczenia są oczywiście elementy kultury w jej węższym ujęciu, takie jak działalność artystyczna, a także zdobycze nauki i techniki. One również stanowią nieodłączną część kompetencji przyszłego użytkownika języka.

Sposób i zakres przekazywania informacji o kulturze kraju docelowego do nauczania języka obcego stały się jednym z wiodących tematów zainteresowań badaczy u schyłku lat 80. ubiegłego wieku. Byram (1989) zaproponował wówczas model nauczania języka i kultury bazujący na czterech wzajemnie powiązanych ze sobą elementach: nauczaniu języka, świadomości językowej, świadomości kulturowej i doświadczeniu kultury. Doświadczenie kultury pomaga w dostrzeżeniu związku między językiem a kulturą, dlatego powinno się odbywać w uporządkowany sposób. Jako punkt odniesienia Byram proponuje perspektywę rodzimego użytkownika języka. Jedną z dróg poznania kultury kraju, którego języka się uczymy, jest zanurzenie się w środowisku danego państwa: wyjazd i bezpośrednie obcowanie z językiem i kulturą. Drugą - przekazywanie wiedzy na temat danego kraju podczas nauki języka obcego.

Jednym z podstawowych źródeł informacji na temat kultury nowego kraju jest podręcznik do nauki języka. Podręcznik jest traktowany jako „pośrednik międzykulturowy" (Tronsoco, 2010), pomoc sprzyjająca rozwojowi świadomości i wrażliwości kulturowej (Byram i Fleming, 1998; Byram, Nichols i Stevens, 2001; Tomlinson, 2000). Dlatego tak ważne jest, aby przedstawione w nim treści stanowiły jak najwierniejszy obraz sytuacji społeczno-kulturowej kraju, gdzie na co dzień używa się języka, którego dany uczeń aktualnie się uczy. Im więcej różnorodnych informacji, dotyczących różnych dziedzin życia, tym bardziej prawdopodobne jest, że uczniowi łatwiej będzie zrozumieć kulturę nowego kraju, co z kolei nie tylko ułatwi mu komunikację z rodzimymi użytkownikami, lecz także zwiększy jego świadomość językową. 


\section{Sytuacja społeczno-kulturowa Szwecji}

W niniejszym opracowaniu zostanie przedstawiony sposób prezentacji sytuacji społeczno-kulturowej Szwecji w podręcznikach do nauki języka szwedzkiego. Mimo podobnego położenia geograficznego i wielu powiązań historycznych uwarunkowania społeczno-kulturowe Polski i Szwecji znacznie różnią się od siebie, dlatego uczeń rozpoczynający naukę języka szwedzkiego powinien móc znaleźć w podręczniku najbardziej charakterystyczne elementy kultury szwedzkiej.

Szwecja jest krajem o dużej powierzchni, lecz stosunkowo niewielkiej liczbie mieszkańców - 9,8 miliona (SCB, 2015) i szybkim tempie przyrostu liczby imigrantów. Od końca II wojny światowej do Szwecji rocznie przybywało kilkadziesiąt tysięcy osób. W ciągu ostatnich dziesięciu lat liczba ta wzrosła do około 100 tys. osób rocznie, a w 2015 roku, w związku z aktualną sytuacją polityczną na świecie, przekroczyła 160 tys. osób (SCB, 2015; Migrationsverket, 2016). Doprowadziło to do tego, że dla wielu mieszkańców Szwecji język szwedzki jest językiem nieprymarnym. Z uwagi na obowiązujące w tym kraju przepisy nie prowadzi się ewidencji osób, uwzględniając kryterium, jakim jest język ojczysty. Istnieje jednak możliwość szacunkowego określenia liczby osób, dla których język szwedzki jest językiem obcym, dzięki danym bazującym na kraju pochodzenia mieszkańców Szwecji ${ }^{1}$ (SCB, 2015). Wynika z nich, że stanowią one $21 \%$ populacji Szwecji, co dwukrotnie przekracza przypuszczenia językoznawców szwedzkich (Domeji, 2010; Parkvall, 2009) mówiących o nieco ponad 10\%. Szczególna sytuacja językowa Szwecji związana z dużą liczbą imigrantów doprowadziła do podjęcia szeregu działań służących integracji nowych mieszkańców. Jednym z nich jest stworzenie systemu nauki języka szwedzkiego jako drugiego zarówno dla dzieci, jak i dorosłych. Dla uczniów, dla których język szwedzki nie jest językiem prymarnym, stworzono przedmiot Svenska som andraspråk (Język szwedzki jako język drugi), dla dorosłych imigrantów gminy oferują bezpłatne kursy zwane Svenska för invandrare (Język szwedzki dla imigrantów). Ponieważ grupy imigrantów są bardzo zróżnicowane, oferowane są trzy rodzaje takich kursów: dla osób nieumiejących w ogóle pisać ani czytać ( $w$ swoim rodzimym języku), dla osób z niewielkim doświadczeniem szkolnym zdobytym przed przyjazdem do Szwecji oraz dla osób, które uzyskały pewne wykształcenie w krajach pochodzenia. W celu dostosowania się do tej sytuacji powstała szeroka gama podręczników do nauki języka szwedzkiego: z jednej strony dla dzieci, dla których język szwedzki jest językiem

\footnotetext{
${ }^{1}$ Za osoby posiadające nieszwedzkie pochodzenie Główny Urząd Statystyczny Szwecji (Statistiska Centralbyrån) uznaje osoby, które są urodzone za granicą, albo osoby urodzone w Szwecji, ale których oboje rodziców urodziło się za granicą.
} 
nieprymarnym, dla dorosłych imigrantów (niepiśmiennych, na niskim stopniu edukacji oraz oswojonych z nauką) oraz dla osób uczących się języka szwedzkiego jako obcego (w różnych instytucjach, przede wszystkim poza Szwecją). Poza językami imigrantów, dzięki przyjęciu Europejskiej karty języków regionalnych lub mniejszościowych, w Szwecji obowiązuje pięć języków mniejszości narodowych ${ }^{2}$ : fiński, meänkieli, języki lapońskie, jidysz i romski. W ostatnich latach na znaczeniu zyskały także dialekty szwedzkie, które są coraz częściej używane w życiu społeczno-politycznym. Duży napływ obcokrajowców pochodzących z ponad 100 państw świata, wysoki status grup mniejszościowych oraz coraz większa świadomość przynależności regionalnej przyczyniają się do tego, że obraz sytuacji społeczno-kulturowej Szwecji jest różnorodny.

Społeczeństwo szwedzkie jest także zróżnicowane pod względem sytuacji rodzinnej. Około 15\% mieszańców żyje w związkach kohabitanckich (w Polsce są to jedynie $2 \%$ ), około $30 \%$ w małżeństwie lub partnerstwie zarejestrowanym (w Polsce 50\% osób jest w związku małżeńskim, partnerstwo rejestrowane nie jest uznane za prawnie usankcjonowaną formę związku). Szwecja ma także jeden z najwyższych w Europie wskaźników rozwodów: 2,8 na 1 tys. mieszkańców, podczas gdy w Polsce jest to 1,7, a średnia UE wynosi 2 (SCB, 2015; GUS, 2015). Od 2009 roku w Szwecji jest także możliwe zawieranie małżeństw jednopłciowych. Dozwolone są zarówno śluby cywilne, jak i kościelne. W świetle powyższych danych społeczeństwo szwedzkie jawi się jako bardzo różnorodne, stąd też przedstawienie owej heterogeniczności w podręcznikach do nauki języka szwedzkiego jako obcego wydaje się być szczególnie istotne.

\section{Społeczeństwo szwedzkie w podręcznikach do nauki języka szwedzkiego jako obcego}

Celem niniejszego opracowania jest próba znalezienia odpowiedzi na cztery podstawowe pytania:

1. Czy różnorodność społeczno-kulturowa Szwecji faktycznie znajduje odzwierciedlenie w podręcznikach do nauki języka szwedzkiego jako obcego?

2. W jaki sposób informacje na ten temat są przekazywane?

3. Czy można zauważyć zmianę w sposobie prezentacji takich informacji na przestrzeni ostatnich dwudziestu lat?

4. Czy poszczególne podręczniki w odmienny sposób przedstawiają różnorodność społeczno-kulturową?

Analizie poddano podręczniki do nauki języka szwedzkiego jako obcego (przygotowane nie dla imigrantów, lecz przeznaczone przede wszystkim dla

\footnotetext{
${ }^{2}$ Pojęcie mniejszości narodowej odpowiada definicji sformułowanej przez Radę Europy.
} 
osób pobierających naukę poza Szwecją) wydane w Szwecji w latach 19962014. Są to dwa podręczniki wraz z ich drugim, zmienionym wydaniem, które ukazało się kilka lat później. Przeznaczone są one do nauki języka od podstaw. Pierwszym podręcznikiem jest Svenska utifrån (dalej jako SU), wydany przez Svenska institutet w roku 1996, którego autorami są Roger Nyborg, Nils-Owe Pettersson i Britta Holm oraz jego kolejna edycja z 2001 roku. Drugim podręcznikiem jest Rivstart $A 1+A 2$ (dalej jako RS), autorstwa Paula Levy Scherrera i Karl Lindemalma, który ukazał się w 2007 roku nakładem wydawnictwa Natur \& Kultur oraz jego poprawiona edycja z 2014 roku. Poszczególne wydania dzieli okres 5-7 lat. Jest to dość równomierne rozłożenie czasowe, a poza tym można się spodziewać, że $w$ takich interwałach zmiany społeczno-kulturowe mogą być bardziej zauważalne niż np. w okresie jednego czy dwóch lat.

Podstawą badań stały się następujące aspekty życia społecznego: sytuacja demograficzna oraz sytuacja rodzinna. Podczas analizy sytuacji demograficznej zwrócono uwagę na ogólne informacje dotyczące mieszkańców, takie jak ich liczba, pochodzenie czy imiona. Przy omówieniu sytuacji rodzinnej analizie poddano sposób życia: samotnie, w związku małżeńskim lub innym związku, narodowość partnerów czy funkcje pełnione w rodzinie.

Informacje na temat sytuacji społeczno-kulturowej mogą się pojawiać explicite i implicite. Za przedstawienie explicite uznawać będziemy tutaj wypowiedzenia deklaratywne, których tematem jest dane zjawisko, np.: „Rdzennymi mieszkańcami Szwecji są Lapończycy" ${ }^{3}$ (RS, 2014: 105). Z przedstawieniem implicite mamy natomiast do czynienia w sytuacji, gdy określony aspekt nie stanowi tematu danego wypowiedzenia, a pojawia się „przy okazji” podawania innych informacji, nie związanych bezpośrednio z sytuacją społecznokulturową. Przykładem może być tekst, w którym na temat wymarzonych zawodów wypowiadają się uczniowie szkoły w Göteborgu. Niektórzy z nich mają obco w szwedzkim brzmiące imiona, np. Mehmed. Za nieszwedzkie uznano imiona, które z jednej strony nie są wymienione wśród 100 najpopularniejszych imion Głównego Urzędu Statystycznego Szwecji (Statistiska Centralbyrån), a przede wszystkim imiona o budowie morfologicznej odbiegającej od szwedzkiej, np. Ayako. Do analizy włączono poza tym prezentację graficzną, która także może - jawnie i niejawnie - przekazywać pewne informacje.

\section{Przedstawienie sytuacji demograficznej - przekaz explicite}

Informacje przedstawiające explicite liczbę mieszkańców Szwecji i ich różnorodność narodowościową znacznie się zmieniały na przestrzeni lat. W najstarszym

\footnotetext{
${ }^{3}$ Wszystkie przykłady zaczerpnięte z omawianych podręczników w tłumaczeniu autora artykułu.
} 
podręczniku (SU, 1996) pojawia się wzmianka: „W Szwecji mieszka ponad 8,5 mln osób. Prawie wszyscy mówią po szwedzku. W Laponii mieszkają Lapończycy, którzy mówią też po lapońsku. W Tornedalen, przy granicy z Finlandią, wiele osób nadal używa fińskiego" (SU, 1996: 30). W kolejnym wydaniu tego samego podręcznika dokonano jedynie aktualizacji liczby mieszkańców (8,9 $\mathrm{mln}$ ), natomiast usunięto pozostałe informacje, które występowały we wcześniejszym wydaniu. Podręcznik RS z 2007 r. także podaje explicite tylko informację o liczbie mieszkańców (9 mln). Z kolei w najnowszym RS z 2014 roku znajdujemy znacznie obszerniejszy opis: „Rdzennymi mieszkańcami Szwecji są Lapończycy. Mają własny język, język lapoński, i własny parlament, Sametinget [...] W Tornedalen, na północy Szwecji, mieszkają także grupy osób mówiących po meänkieli" (RS, 2014: 105).

Różnorodność narodowościowa Szwecji pojawia się także w związku z informacją o numerach ewidencyjnych: „Wszyscy mieszkańcy Szwecji, Szwedzi i ok. 400000 obywateli innych państw, mają swój numer ewidencyjny" (SU, 1996: 25). Poza tym, powołując się na dane Statistiska Centralbyrån, wymieniono w liczbach cztery populacje imigrantów: Finów, Niemców, Jugosłowian i Greków (SU, 1996: 25). Pięć lat później podręcznik ten aktualizuje liczbę imigrantów do 500 tys., a wymieniając cztery narodowości najliczniej zamieszkujące Szwecję, wskazuje Finów, Niemców, Bośniaków i Irakijczyków. Należy zwrócić uwagę na fakt, że dane te nie są do końca prawdziwe, gdyż faktycznie wtedy najwięcej było osób pochodzenia fińskiego, natomiast kolejne miejsca zajmowali emigranci z Jugosławii, Iranu i Niemiec (w 1990 roku) ${ }^{4}$ oraz Jugosławii, Bośni i Hercegowiny, Iranu i Iraku (w 2000 roku). Mimo zwrócenia uwagi na dużą liczbę osób o pochodzeniu innym niż szwedzkie podręcznik ten w obydwu swoich wydaniach przekazuje raczej homogeniczny narodowościowo obraz społeczeństwa: „Oto Szwecja: [...] wysokie podatki, dobrobyt, wysokie kobiety z włosami blond i wysocy, małomówni mężczyźni” (SU 1996, 2001: 154). W nowszym podręczniku, w pierwszym wydaniu, nic nie jest napisane explicite o różnorodności narodowościowej Szwecji, natomiast w drugim, z 2014 roku, pojawiają się dwie wzmianki: „W Malmö mieszkają osoby pochodzące z wielu krajów” (RS, 2014: 101) oraz ogólnie przedstawiona jest historia imigracji do Szwecji, zakończona stwierdzeniem: „Prawie jedna piąta osób mieszkających obecnie w Szwecji urodziła się za granicą lub ich rodzice urodzili się za granicą" (RS, 2014: 105).

4 Mimo publikacji podręcznika w 1996 roku autorzy przytoczyli dane z roku 1989/1990. Obecnie nadal najliczniejszą grupą osób z nieszwedzkim pochodzeniem stanowią Finowie, na kolejnych jednak miejscach znajdują się Irakijczycy, narody zamieszkujące obszary dawnej Jugosławii oraz - na czwartym miejscu - Polacy. 


\section{Przedstawienie sytuacji demograficznej - przedstawienie implicite}

Część informacji odnosząca się do różnorodności społeczno-kulturowej została przedstawiona w podręcznikach w sposób niejawny, implicite. W niniejszym opracowaniu analizie poddano wszystkie imiona, które występują w podręcznikach, związki dwunarodowościowe oraz pojawienie się na ilustracjach osób, których wygląd odbiega od "typowo szwedzkiego”.

W analizowanych podręcznikach widoczny jest wyraźny wzrost różnorodności występowania imion nieszwedzkich (zob. wykres 1). Jednocześnie występują znaczne różnice między obydwoma podręcznikami. W podręczniku starszym, w obu jego wydaniach, jedynie cztery spośród 141 różnych imion (około 3\%) można uznać za imiona nieszwedzkie: Ebon (hiszpańskie), Kenta (japońskie), Ayako (japońskie) oraz Taija (fińskie). W podręczniku Rivstart z 2007 roku pojawia się 20 takich imion, a w wydaniu z 2014 roku - 26, co stanowi około $20 \%$ wszystkich użytych antroponimów. Być może odsetek ten jest przypadkowy, pokrywa się on jednak z przytoczonym powyżej odsetkiem mieszkających w Szwecji osób pochodzenia nieszwedzkiego.

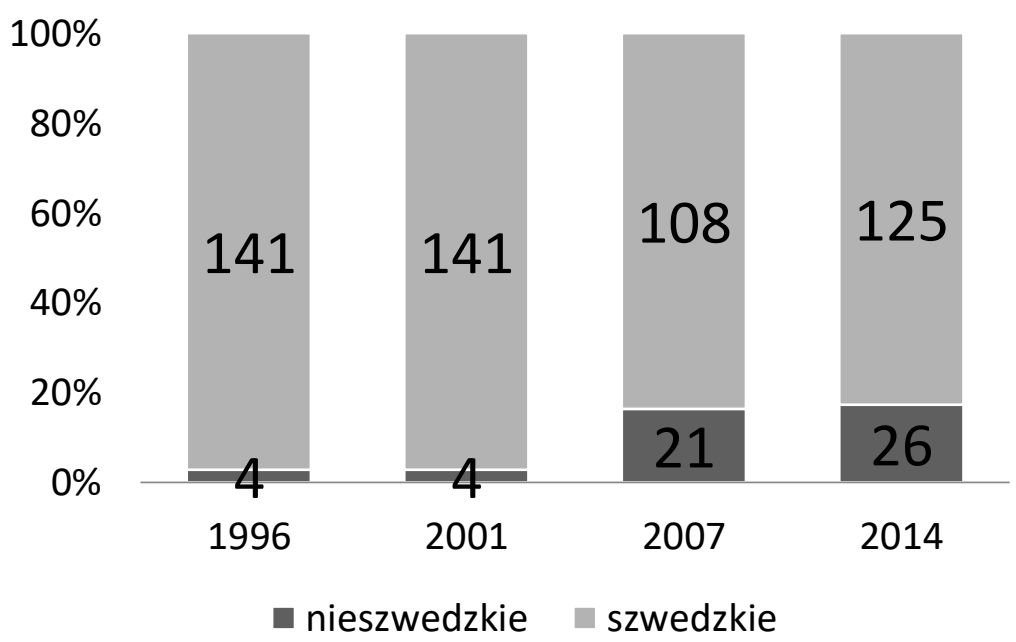

Wykres 1: Imiona pojawiające się w podręcznikach.

W podręczniku SU z 1996 roku jedynie dwa spośród jedenastu małżeństw okazują się być związkami dwunarodowościowymi: jedna para jest szwedzko-fińska, druga szwedzko-japońska. Co ciekawe, przedstawicielem owego szwedzko-japońskiego małżeństwa jest jeden z autorów podręcznika. Pięć lat później, w kolejnym wydaniu Svenska uitfrån, sytuacja ta nie ulega 
zmianie. W podręczniku z 2007 roku aż 40\% par (zarówno małżeństw, jak i związków konkubenckich) to związki dwunarodowościowe, a w najnowszym wydaniu RS z 2014 roku odsetek ten wzrasta aż do 46\%.

Podobną tendencję można także zauważyć w odniesieniu do graficznej prezentacji różnorodności narodowościowej (zob. wykres 2). Spośród wszystkich ilustracji, na których można było wyodrębnić twarze, w obydwu wydaniach SU niespełna 6\% osób można było uznać za osoby o pochodzeniu nieszwedzkim, podczas gdy w obu wydaniach RS odsetek takich osób wynosi niemal 40\%. Przy identyfikowaniu osób sklasyfikowanych w niniejszym opracowaniu jako osoby o wyglądzie nieszwedzkim - z czego implicite można wyciągnąć wniosek o nieszwedzkim pochodzeniu - skupiono się na ilustracjach przedstawiających osoby o ciemnej karnacji, wyglądzie powszechnie uznanym za azjatycki, arabski czy afrykański. Przy takim wyodrębnianiu uwzględniono także przytoczony wcześniej opis z podręcznika Svenska utifrån: że typowi Szwedzi są wysocy i mają jasne włosy.

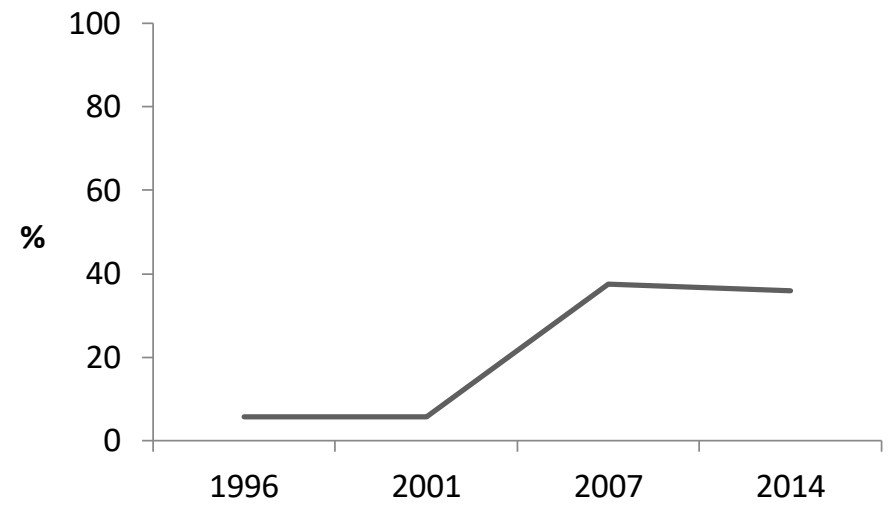

Wykres 2: Różnorodność społeczno-kulturowa przedstawiona na ilustracjach.

\section{Sytuacja rodzinna - przedstawienie explicite}

Podobnie jak w przypadku sytuacji demograficznej, także i sytuacja rodzinna w Szwecji ulegała zmianom, co znalazło odzwierciedlenie w omawianych podręcznikach. W Svenska utifrån z roku 1996 explicite podano następujące informacje:

- 3 mln Szwedów jest w związku małżeńskim;

- rośnie liczba osób mieszkających samotnie;

- 700 tys. Szwedów żyje w związkach kohabitanckich;

- $\quad$ ostatnio bardziej popularne jest zawieranie związków małżeńskich niż życie w konkubinacie; 
- nie ma większych różnic między małżeństwem a konkubinatem (SU, 1996: 145).

W opublikowanym pięć lat później wydaniu tego podręcznika nie zostały dokonane żadne zmiany dotyczące przedstawienia sytuacji rodzinnej.

W RS z 2007 roku pojawiają się informacje, że można żyć w związku małżeńskim, w konkubinacie, mieć chłopaka/dziewczynę lub być singlem (RS, 2007: 15). Różnorodność form życia niemałżeńskiego przedstawiono ponadto, wymieniając różne określenia, gdzie ensam oznacza mieszkanie samemu, sambo - w konkubinacie, särbo - mieszkanie osobno, ale bycie w związku, iblandbo - bycie w związku, ale wspólne mieszkanie tylko od czasu do czasu, a mambo - mieszkanie dorosłej osoby z rodzicami (RS, 2007: 167). Jednocześnie w podręczniku podkreślono, że Szwecja ma najwięcej, bo aż $46 \%$ gospodarstw jednoosobowych w Europie (RS, 2007: 167). Dla porównania w Polsce odsetek ten wynosi $24 \%$ (GUS, 2015).

W najnowszym podręczniku, wydanym w 2014 roku, czyli pięć lat po wprowadzeniu w Szwecji małżeństw jednopłciowych, znajduje się informacja, że takie małżeństwa są w Szwecji prawnie dozwolone (RS, 2014: 14). Poza tym dokładnie opisane są różne modele życia rodzinnego: „Kiedy rodzice się rozstaną, a potem poznają nowego partnera, który też ma dzieci, dzieci dostają przyszywane rodzeństwo, a rodzice dostają pasierbów. Nowy facet mamy to przyszywany tata albo tata na niby. W rodzinie tęczowej mogą być dwie mamy lub dwaj tatowie". (RS, 2014: 59). W odniesieniu do gospodarstw jednoosobowych, poza wymienioną we wcześniejszym wydaniu informacją o największym w Europie odsetku takich gospodarstw, dodano wzmiankę, że w Sztokholmie odsetek ten wynosi aż 60\% (RS, 2014: 177).

\section{Sytuacja rodzinna - przedstawienie implicite}

Informacje o różnorodności sposobów życia są przekazywane także pośrednio w tekstach i ćwiczeniach. W okresie niemal 20 lat, który dzieli publikacja pierwszego i ostatniego wydania omawianych pozycji, dywersyfikacja życia rodzinnego w podręcznikach uległa znacznemu wzrostowi, co ilustruje wykres 3. W podręczniku SU z 1996 roku niemal wszystkie pary występujące w różnych kontekstach są małżeństwami. Jedynie w dwóch przypadkach osoby będące w związku nie są małżeństwem, lecz partnerami mieszkającymi osobno. Sytuacja ta nie ulega zmianie w późniejszym wydaniu. Zupełnie inny obraz życia rodzinnego otrzymujemy, analizując treści podręcznika Rivstart z 2007 roku. Tam małżeństwa stanowią tylko jedną czwartą wszystkich opisywanych par, najwięcej, bo aż niemal dwie trzecie związków przedstawianych w czytankach i 
ćwiczeniach stanowią pary żyjące w konkubinacie. W jednym z tekstów pojawia się także rodzic samotnie wychowujący dziecko. Znacznie bardziej różnorodnie społeczeństwo szwedzkie przedstawione zostało w najnowszym wydaniu tego podręcznika z 2014 roku. Podobnie jak w poprzedniej edycji małżeństwa stanowią co czwartą parę wymienianą w tekstach czy ćwiczeniach leksykalno-gramatycznych. Poza konkubinatem i samotnymi rodzicami, obecnymi w wydaniu z 2007 roku, w tej opisano także pary mieszkające osobno, singli oraz dorosłe osoby mieszkające razem z rodzicami.

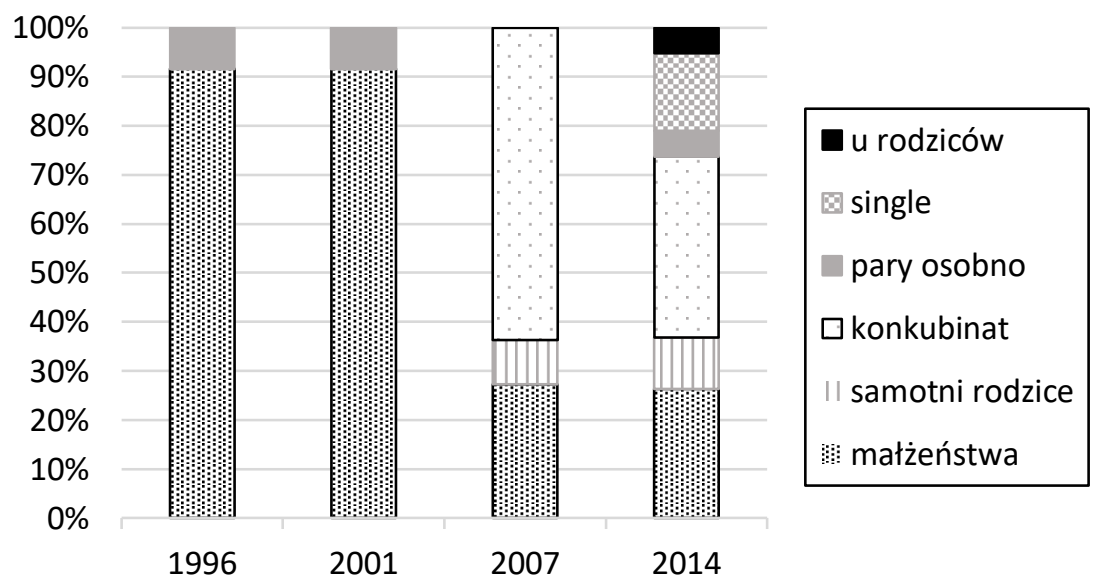

Wykres 3: Różnorodność form życia społecznego w podręcznikach - implicite.

Poza tym w podręczniku z 2014 roku pojawiają się także podane w sposób implicytny informacje o związkach jednopłciowych. W jednym z dialogów występuje Agnes (imię żeńskie), która ma dziewczynę o imieniu Kicki (RS, 2014: 14). Z kolei w ćwiczeniu na rozpoznawanie podmiotu i dopełnienia występują partnerzy Pelle i Uffe (imiona męskie), którzy mają piękny dom (RS, 2014: 157). W ćwiczeniu na zaimki pojawia się informacja o małżonkach o imieniu Bengt i Kenneth - obydwa imiona są męskie (RS, 2014: 22).

W podręcznikach ukazano także zróżnicowanie ról w związku. O ile w obydwu starszych materiałach we wszystkich występujących tam związkach obowiązuje raczej podział tradycyjny, o tyle w podręczniku Rivstart dostrzec już można istotne zmiany. W 2007 roku w podrozdziale, którego celem jest nauczenie pisania e-maili, pojawia się przykład:

„Cześć Magnus!

Przesyłam Ci dokument, o który prosiłeś. Przepraszam, że wysyłam go tak późno.

Pozdrowienia Kalle" (RS, 2007: 182). 
W roku 2014 w odpowiednim podrozdziale zamiast tego tekstu pojawia się przykład zupełnie innego e-maila:

\begin{abstract}
„Cześć Anneli!
Nora zachorowała, więc muszę wziąć dzień opieki nad dzieckiem. Byliśmy umówieni na dzisiaj na drugą. Czy możemy przesunąć nasze spotkanie na najbliższy poniedziałek o tej samej godzinie?
\end{abstract}

Pozdrowienia Mats" (RS, 2014: 197)

W tekście tym wyraźnie widać, że to mężczyzna (Mats), a nie kobieta zostaje $\mathrm{z}$ chorym dzieckiem $\mathrm{w}$ domu. $\mathrm{W}$ tym samym podręczniku, w obydwu wydaniach, zamieszczono także tekst o małżeństwie o imionach Fatoush i Tomas (RS, 2007) oraz odpowiednio Selin i Tomas (RS, 2014), gdzie żona to świetnie zarabiający mikrobiolog z doktoratem, natomiast mąż jest tłumaczem pracującym w domu, zajmującym się dziećmi oraz wykonującym wszystkie prace domowe: sprzątanie, pranie, zakupy itp. Powyższe przykłady obrazują nie tylko duże zróżnicowanie społeczeństwa, lecz także szybkie dostosowanie treści w podręczniku do zmian, jakie w nim następują.

\title{
9. Podsumowanie
}

Podczas nauki języka obcego w sytuacji szkolnej poza krajem, w którym język ten jest językiem codziennej komunikacji, doświadczanie kultury nowego kraju najczęściej odbywa się dzięki treściom zawartym w podręczniku do nauki języka. Dlatego tak ważne jest, aby informacje w tym materiale dydaktycznym możliwie najwierniej i najpełniej ukazywały aktualną sytuację społeczno-kulturową kraju docelowego. Jest to szczególnie istotne, gdy określone aspekty życia zasługują na specjalną uwagę, gdyż znacznie różnią się od tego, co w danej kulturze, w danym makroregionie czy na danym kontynencie jest traktowane jako norma.

Szwecję można uznać za kraj o dużym zróżnicowaniu społeczno-kulturowym z uwagi na bardzo wysoki odsetek imigrantów zamieszkujących ten kraj, dużą liczbę rozwodów oraz usankcjonowanie prawne związków partnerskich i małżeństw jednopłciowych. Przedstawienie tych aspektów w podręcznikach z pewnością ułatwi poznanie kultury szwedzkiej, wpłynie na lepsze zrozumienie zachowania się mieszkańców Szwecji i dzięki temu ułatwi późniejszą komunikację uczniom uczącym się języka szwedzkiego.

Analiza czterech podręczników do nauki języka szwedzkiego jako obcego, a właściwie dwóch pozycji wydanych z poprawkami po 5-7 latach, wykazała z jednej strony znaczny wzrost ilości informacji dotyczących różnorodności społeczno- 
kulturowej Szwecji w okresie niemal dwudziestu lat (od 1996 do 2014 roku), z drugiej - różnice między obydwoma podręcznikami. Zróżnicowanie społeczeństwa szwedzkiego przedstawiane jest w podręcznikach zarówno explicite, jak i implicite. W obu wydaniach starszego podręcznika Svenska utifrån (z 1996 i 2001 roku) dane o Szwecji i jej mieszkańcach są podawane jawnie i dotyczą głównie dużej liczby imigrantów. Społeczeństwo szwedzkie zostało zobrazowane jako raczej homogeniczne, z małżeństwem jako podstawową formą życia rodzinnego. Mimo sygnalizowanego zróżnicowania narodowościowego związki dwunarodowościowe występują w tym podręczniku bardzo rzadko, a role $w$ rodzinie przedstawiane są tradycyjnie.

Zupełnie innym podręcznikiem jest Rivstart, którego wydania z 2007 i 2014 roku nie tylko ukazują duże zróżnicowanie społeczeństwa, lecz także podążają za bieżącymi zmianami społeczno-politycznymi. Rivstart różni się od Svenska utifrån liczbą informacji przekazanych implicite. Podczas gdy w podręcznikach z 1996 i 2001 roku dane o sytuacji rodzinnej i demograficznej Szwecji pojawiały się głównie explicite, w obydwu wersjach Rivstart uczeń otrzymuje odpowiednie informacje nie tylko wprost, dzięki czemu różnorodność społeczno-kulturowa niemal naturalnie staje się częścią wiedzy o Szwecji. Podręcznik ten w wielu miejscach opisuje Szwecję jako kraj, w którym związki dwunarodowościowe są powszechne, większość par nie żyje w związku małżeńskim, a pary jednopłciowe są usankcjonowane prawnie. Zróżnicowaniu form związków towarzyszy zmiana podziału obowiązujących w nim ról.

Podsumowując, można stwierdzić, że analizowane podręczniki do nauki języka szwedzkiego odzwierciedlają społeczno-kulturową różnorodność Szwecji, starają dopasować swoje treści do zmian, które zachodzą w społeczeństwie szwedzkim, i dlatego można je traktować jako wiarygodne źródło wiedzy o kulturze Szwecji. Na szczególną uwagę zasługuje podręcznik Rivstart, który zadanie to spełnia znacznie lepiej niż Svenska utifrån.

\section{BIBLIOGRAFIA}

Byram, M. 1989. Cultural Studies in Foreign Language Education. Clevedon - Philadelphia: Multilingual Matters.

Byram, M. i M. Fleming. 1998. Language Learning in Intercultural Perspective. Cambridge: Cambridge University Press.

Byram, M., Nichols, A. i D. Stevens. 2001: „Introduction”. (w) Languages for Intercultural Communication and Education, 1: Developing Intercultural Competence in Practice. (red. M. Byram, A. Nichols i D. Stevens). Clevedon: Multilingual Matters Limited, str. 1-8.

Domeji, R. 2010. „Elektronisk kommunikation - möjligheter och svårigheter”. Wykład wygłoszony podczas konferencji ASLA. Språk för framtiden. Falun, 12-13 listopada 2010. 
Encyklopedia PWN. [online: http://encyklopedia.pwn.pl/haslo/kultura;3928887.html; DW 8.01.2016].

Główny Urzq̨d Statystyczny. 2015. [online: http://stat.gov.pl/obszary-tematyczne/ludnosc/ ludnosc/ludnosc-stan-i-struktura-ludnosci-oraz-ruch-naturalny-w-przekroju-ter ytorialnym-stan-w-dniu-31-xii-2014-r-,6,17.html; DW 8.01.2016].

Migrationsverket. 2016. [online: http://migrationsverket.se; DW 8.01.2016].

Parkvall, M. 2009. Sveriges språk. Vem talar vad och var? RAPPLING 1. Rapportert från institutionen för lingvistik. Stockholms universitet.

Słownikjęzyka polskiego. [online: http://sjp.pwn.pl/sjp/kultura;2565197.html; DW 8.01.2016]. Statistik för alla 2015/2016. 2015. Örebro: Statistiska Centralbyrån. [online: http://scb.se; DW 8.01.2016].

Tomlinson, B. 2000. „Materials for cultural awareness: combining language, literature and culture in the mind". The Language Teacher, 24(2): 19-21.

Tronsoco, C. R. 2010: „The effects of Language Materials on the Development of Intercultural Competence". (w) Research for Materials Development in Language Learning: Evidence for Best Practice. (red. B. Tomlinson i H. Masuhara). London: GBR: Continuum International Publishing, str. 83-102.

Wielki słownik języka polskiego. [online: http://wsjp.pl/index.php?id_hasla=3479\&ind= 0\&w_szukaj=kultura; DW 8.01.2016]. 